\title{
TEMBANG (LAGU) DOLANAN ANAK SEBAGAI INSPIRASI PENCIPTAAN TARIAN ANAK
}

\author{
Untung Muljono 1 \\ Institut Seni Indonesia Yogyakarta
}

\begin{abstract}
Tembang Dolanan Anak is a creation (fruit of thought) or the composition of the language with the rules of the standard (gumathok) which way of reading it must be dilagukan by using the beauty of sound owned. Tembang (sekar) Java is divided into two categories, namely classic and folk type. The classical tembang is a tembang whose source is from the Javanese royal court from the time of Kediri to Mataram Islam (Yogyakarta and Surakarta), therefore the rules are very strict. The song that developed in the people's circle (in the Hindu era belongs to the caste of waisya and sudra) the mention is "song, lagon, or lelagon" there is no binding rule (free) only certain songs. Types of Dolanan Tembang Anak many developed in society that tell about behavior pattern and character owned by children. Therefore Tembang Dolanan Anak has a noble value education on the meaning contained in it. It inspires children's dance making. The method used in applying in the form of child dance that is with the approach of phenomenology with emphasis on the strength of creative ideas creation by Edmund Huserr. Phenomenology in his view does not make the object a fact but rather abstracts the objects.

The results obtained by looking at the source of inspiration from Tembang Dolanan Anak make the child dance more meaningful in the forms of movement that was created. The choreography created can be tailored to the child's character and behavioral patterns.
\end{abstract}

Keywords: Dolanan Children Tembang, Inspiration, Child Dance

\begin{abstract}
Abstrak
Tembang Dolanan Anak merupakan sebuah ciptaan (buah pikiran) atau susunan bahasa dengan aturan-aturan baku (gumathok) yang cara membacanya harus dilagukan dengan menggunakan keindahan suara yang dimiliki. Tembang (sekar) Jawa terbagi dalam 2 kategori yaitu jenis klasik dan jenis rakyat. Tembang klasik adalah tembang yang sumbernya dari istana kerajaan Jawa sejak jaman Kediri hingga Mataram Islam (Yogyakarta dan Surakarta), oleh karena itu aturan-aturannya sangat ketat. Tembang yang berkembang dilingkungan rakyat (pada jaman Hindu tergolong kasta waisya dan sudra) penyebutannya adalah "lagu, lagon, atau lelagon" tidak ada aturan yang mengikat (bebas) hanya lagunya yang sudah tertentu. Jenis Tembang Dolanan Anak banyak berkembang dalam masyarakat yang menceritakan tentang pola tingkah laku dan karakter yang dimiliki oleh anak-anak. Oleh karena itu Tembang Dolanan Anak memiliki
\end{abstract}

\footnotetext{
${ }^{1}$ Dosen Jurusan Sendratasik FSP ISI Yogyakarta.
} 
pendidikan nilai luhur pada makna yang terkandung di dalamnya. Hal itu menginspirasi untuk pembuatan tarian anak.

Metode yang dipergunakan dalam mengaplikasikan dalam bentuk tarian anak yaitu dengan pendekatan fenomenologi dengan penekanan pada kekuatan struktur ide kreatifitas penciptaan oleh Edmund Huserr. Fenomenologi dalam pandangannya tidak membuat obyek menjadi fakta melainkan mengabstraksi obyek-obyek itu.

Hasil yang didapatkan dengan melihat sumber inspirasi dari Tembang Dolanan Anak menjadikan tarian anak lebih bermakna dalam bentuk-bentuk gerakan yang diciptakan. Koreografi yang dibuat dapat disesuaikan dengan karakter dan pola tingkah laku anak.

Kata Kunci: Tembang Dolanan Anak, Inspirasi, Tarian Anak

\section{Pendahuluan}

Proses pembelajaran musik vokal maupun instrumental di sekolah -sekolah baik Taman Kanak-Kanak, Sekolah Dasar, dan Sekolah Menengah Pertama/Atas selama ini belum berjalan seperti yang diharapkan, karena pelaksanaannya sebagian besar masih bersifat teoritis. Keadaan ini berakibat pada pembelajaran musik vokal (tembang) dan instrumental yang seharusnya menjadi sarana untuk berolah rasa dan berolah ketrampilan bermusik, kenyataannya hanyalah berupa pelajaran teori yang lebih mengarah dan menekankan ranah kognitif dan psikomotorik menjadi terabaikandan terlupan (Wicaksono, 2007: 52).

Menentukan materi pendidikan tembang (lagu) dolanan anak-anak khususnya di sekolah taman kanak-kanak dan sekolah dasar yang sesuai dengan perkembangan usia anak tidak mudah, hal ini karena pengaruh perkembangan teknologi informasi dengan mudah dan cepat dinikmati dan didapatkan dilingkungan rumah (keluarga) maupun di masyarakat setiap saat. Bahkan di dalam kendaraan umumpun mendapatkan pelayanan audio visual secara gratis dan menghibur dengan lagu-lagu percintaan yang menggairahkan. Namun, pada bahasan mengenai tembang (lagu) dolanan anak-anak sebagai pokok bahasan hendaknya dapat dimasukan materi muatan lokal guna tercapainya tujuan pembelajarannya. Sebagai musik vokal tembang (lagu) merupakan karya kreatif manusia yang mencerminkan sikap dan perhatian serta ungkapan terhadap keindahan yang diungkapkan melalui medium bunyi (suara mulut). Apa yang terkandung di dalam musik vokal dapat dimanfaatkan untuk mengolah rasa bagi anak-anak.

Dari prespektif psikologi perkembang anak, musik vokal (tembang) sangat tepat diajarkan pada usia dini (pra sekolah) 2-5 tahun dan usia sekolah 6-12 tahun. Pada usia 2-5 tahun pertumbuhan fisik berjalan terus dan lebih serasi sebagai seorang manusia yang utuh, dimana keserasian tubuh dengan gerakan yang luwes, perbendaraan kata dalam bicara semakin banyak, 
membangun komunikasi dalam lingkungannya semakin luas. Yang perlu diperhatikan, bahwa pada usia ini yang paling menonjol adalah perkembangan motoriknya yaitu segala sesuatu yang ada hubungannya dengan gerakan-gerakan tubuh. Pada usia 6-12 tahun anak memasuki masa belajar baik di dalam maupun di luar sekolah. Aspek perilaku dibentuk melalui penguatan verbal, keteladanan dan identifikasi. Dalam perkembangannya anak tetap memerlukan penambahan pengetahuan melalui belajar secara sistematis di sekolah serta mengembangan sikap dan kebiasaan dalam keluarga. Campbell mengemukakan bahwa pembentukan pribadi perlu dilakukan sejak usia dini (Campbell, 2001: 228-229):

....karena pada usia dini itulah imajinasi harus dirangsang, dan kesempatan bagi pertumbuhan emosi, yang mengandung penglaman untuk merasa, dan kemampuan untuk mengendalikan ekspresi perasaan tersebut, harus pula diberi ruang. Segala sesuatu yang dialami seorang anak kecil pada usia dini, segala sesuatu yang merupakan faktor penentu bagi seluruh hidupnya.

Ki Hadjar Dewantara dalam bukunya yang berjudul Sari Swara mengatakan: bahwa pelajaran tembang (sekar) atau gending Jawa untuk anak Jawa itu, amat besar memberikan kekuatan dalam membentuk budi perkerti yang halus, memantapkan rasa kebangsaan serta menguasai dalam belajar sastra. Oleh karena itu di Negara manapun juga, pelajaran tembang itu dalam pelajaran termasuk masalah yang amat diperhatikan.

Kiranya cukup jelas manfaat pendidikan atau mata pelajaran musik vocal (tembang) pada anak-anak usia sekolah (TK maupun SD). Untuk dapat mengoptimalkan pembelajaran dengan capaian pembentukan kepribadian, maka pelaksanaannya harus benar, terutama memilih tema tembang dan materi lagunya.

\section{Pengertian dan Jenis Tembang}

Kata tembang sebuah penyebutan etnis yang berlaku di daerah Jawa, Sunda, dan Bali. Diluar etnis tersebut (Jawa, Sunda, dan Bali) secara umum dengan penyebutan lagu daerah. Tembang artinya "syair, nyanyian, puisi" (Prawiroatmojo, 1957: 250). Lebih lengkap diuraikan dalam Ngengrengan Kasusastran Djawa II, adalah:

Reriptan utawa dhapukaning basa mawa paugeran tartamtu (gumathok) kang pamacane (olehe ngucapake) kudu dilagokake nganggo kagunan swara. 
Maksudnya kurang lebih: Ciptaan (buah pikiran) atau susunan bahasa dengan aturan-aturan baku (gumathok) yang cara membacanya harus dilagukan dengan menggunakan keindahan suara yang dimiliki.

\section{Jenis Tembang}

Tembang (sekar) Jawa terbagi dalam 2 kategori yaitu jenis Klasik dan jenis rakyat. Tembang klasik adalah tembang yang sumbernya dari istana kerajaan Jawa sejak jaman Kediri hingga Mataram Islam (Yogyakarta dan Surakarta), oleh karena itu aturan-aturannya sangat ketat. Tembang yang berkembang dilingkungan rakyat (pada jaman Hindhu tergolong kasta waisya dan sudra) penyebutannya adalah "lagu, lagon, atau lelagon" tidak ada aturan yang mengikat (bebas) hanya lagunya yang sudah tertentu (Depdikbud, 1980: 9), di Bali penyebutannya gegendingan atau sekar rare (Aryasa, 1984: 12).

Melacak jenis tembang, struktur, peran dan fungsi khususnya di Jawa, memerlukan waktu dan kecermatan, tidak dekian halnya yang terjadi di Bali, dimana disamping usaha pelestarian secara posisitif, tembang merupakan bagian tak terpisahkan dalam upacara keagamaan dalam agama Hindhu (Aryasa, 1984: 2). Pengaruh Islamisasi dalam sistim pemerintahan secara berturut-turut Demak, Panjang, Mataram (Yogyakarta dan Surakarta) tembang mengalami pergeseran peran fungsinya dalam kebudayaan. Pada akhirnya tembang hanya sebagai warisan budaya baik yang masih ada di istana Yogyakarta dan Surakarta maupun yang berkembang di masyarakat diluar istana (Jawa Tengah dan Jawa Timur).

\section{Tembang}

Menurut jenisnya tembang yang berkembang di Jawa terbagi menjadi tiga bagian yaitu: Tembang Gedhe (Sekar Kawi/Kawin), Tembang Tengahan (Sekar Tengahan), dan Tembang Macapat (Sekar Alit). Ketiga jenis tembang (sekar) ini masing-masing mempunyai aturan satu sama lain berbeda.

a. Tembang Gedhe (Sekar Ageng)

Biasanya pada bagian judul tembang ditulis lampah dan pedotan. Lampah atau laku adalah jalannya lagu dalam satu baris tembang, misalnya:

- Judul : Sekar Ageng Gandakusuma

- Laras: Pelog pathet Bem.

- Lampah : 24, pedotan (6.6.6.6) 
1). $5 \underline{6 \mathrm{i}} \underline{\underline{\mathrm{i} .65}} \underline{\underline{6.5 .6}} \underline{\underline{23}} \underline{1.2 .16} .0$

Ha- nan- ta na- ren- dra

$5 \underline{6 \mathrm{i}} \underline{\mathrm{i} .65} \underline{6.5 .6} \underline{23} \underline{1.2 .1 .6} .0$

Ra- gu pu- tra ma- ring

$666 \underline{12} \cdot \underline{23} \cdot \underline{3.4 .5 .4 .3} \cdot 0$

Ra- ta pi- we- weh- nya

$\underline{6 \mathrm{I}} \underline{1.23 .2 .16 .5 .32} .2 \underline{23} \underline{3.21} \underline{1.2 .16} .00$

Hyang Hen- dra ring si- ra

2). $\underline{23} \quad 1.612 \underline{35.6} \cdot 0$

Ka- pya pra Ja-wa- ta

$\begin{array}{lllllllll}2.3 & 1 & . & 6 & 1 & 2 & 3 & 0\end{array}$

Ngan- ta- rik- sa umyung

$6 \underline{5.32} \cdot 2 \underline{35} \underline{56} \underline{5.6 .53} \cdot 0$

Dan a- ngu- dan- a- ken

$\underline{6 \mathrm{i}} \underline{\mathrm{i} 23.2 . \mathrm{i} 6.5 .32} \cdot 2 \underline{23} \underline{\underline{3.21}} \underline{1.2 .16} \cdot 00$

Tang Gan- da ku- su- ma

3). $\underline{23} \quad 1 \quad 6 \quad 6 \quad 1 \quad 2 \quad \underline{35.6} \cdot 0$

Mu- lat- a si- ra Sang

$\begin{array}{llllllllll}2 & 3 & 1 & 6 & 1 & 2 & 3 & 0\end{array}$

Wi- bi- sa- na angling

$6 \underline{5.32} \cdot 2 \underline{35} \underline{56} \cdot \underline{6.6 .53} \cdot 0$

Ja- ya ja- ya ja- ya

$\underline{6 \mathrm{i}} \mathrm{i} .23 .2 . \mathrm{i} 6.532 \cdot 2 \underline{23} \underline{3.21} \cdot \underline{1.2 .16} .00$

Ja- yeng nar-pa pu- tra

4). $\quad \underline{2.3} \quad 1 \quad 6 \quad 1 \quad 2 \quad \underline{35.6} \cdot 0$

Da- sa mu-ka si- ra

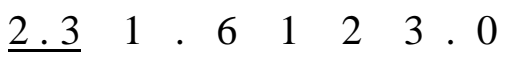

Ja- ti wi- dig- da- ya 
$\begin{array}{llllllll}6 & \underline{5.3 .2} & 2 & 2 & 2 & 2 & 0\end{array}$

A- mung pa-kar-ti- nya

$222 \quad 2 \quad \underline{35} \underline{56} \underline{5.6 .53} .00$

Tansu-rut ngru- ru- suh

Lampah 24 artinya dalam satu baris tembang gedhe, sama dengan sagatra dalam tembang macapat (Ki Hadjar Dewantara, 1964, 13) terdiri dari 24 suku kata (wanda) yang terbagi dalam 4 pedotan (6, 6, 6, 6 suku kata). Sekar Ageng terdiri dari 4 baris (24 lampahX4) dengan penyebutan: Satu baris disebut Sapada Pala, 2 baris disebut Sapada Dirga, dan 2 Pada Dirga disebut Sapadeswara.

b. Tembang Tengahan (Sekar Tengahan)

Tembang tengahan ditentukan oleh guru wilangan (wanda) dan guru lagu (pada lingsa/ hurup hidup kata akhir) yang khas. Dalam perkembangannya, tembang tengahan disebut tembang dagelan, termasuk dalam rumpun tembang macapat, hal ini dapat kita lihat pada strukturnya yang hampir sama dengan struktur tembang macapat, misalnya: tembang megatruh dan dudukwuluh. Tembang tengahan pada umumnya digunakan untuk memulai sebuah gending atau mbawani sebuah gending, misalnya; tembang tengahan Pranasmara untuk mbawani gending Tarupala. Contoh tembang tengahan:

\begin{tabular}{|c|c|}
\hline Judul & $\begin{array}{l}\text { : Tembang Tengahan Pranasmara } \\
(8 \mathrm{a}, 11 \mathrm{e}, 12 \mathrm{e}, 8 \mathrm{a}, 8 \mathrm{a}, 8 \mathrm{i})\end{array}$ \\
\hline Laras & : Slendro Patet Manyuro \\
\hline & $6 \quad 6 \quad \mathrm{i} \quad \underline{2 . i 6}$ \\
\hline & NengKarangdempel le- \\
\hline & $\underline{2 \mathrm{i}} \quad \mathrm{i} \quad \mathrm{i} \quad \mathrm{i} \quad \underline{\mathrm{i} 2} \underline{\mathrm{i} 6} \mathrm{i} \quad \underline{23.2 . \mathrm{i} 6}$ \\
\hline & rah Se-mar sa- pra- nak-a- ne \\
\hline & $\begin{array}{llllllllll}6 & \underline{6 \mathrm{i} 2} & \underline{6356 \mathrm{I} 65} & \underline{3.532} & 3 & 3 & 3 & 3 & 6 & 5\end{array}$ \\
\hline & bon ke- bon te- gal a- le- ren \\
\hline & $\begin{array}{llllllll}6 & \underline{6 \mathrm{i} .2} & \underline{6.53} & \underline{5.6} & 2 & 2 & \underline{235.32} & \underline{16}\end{array}$ \\
\hline & Sa- mi ngu- nduh ta- ru- pa- la \\
\hline
\end{tabular}




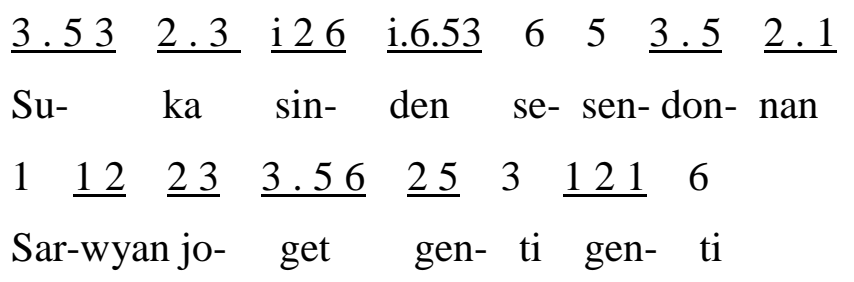

\section{c. Tembang Macapat (Sekar Alit)}

Tembang macapat (sekar alit) adalah tembang yang paling popular ditengah-tengah komunitas Jawa dimanapun berada, karena disamping tata bahasanya mudah dipahami, pola lagu serta temponya lebih variatif (banyak pilihan). Seperti tembang tengahan, tembang macapat dengan ciri-ciri terdiri dari; guru gatra, guru lagu (pada lingsa), guru wilangan. Nama-nama tembang macapat tersebut ; Pocung, Maskumambang, Kinanthi, Gambuh, Megatruh, Mijil, Asmaradana, Pangkur, Sinom, Dhandhanggula, dan Durma. Contoh tembang macapat:

Judul : Tembang Macapat Asmaradana (8i, 8a, 8e/a, 8a, 7a, 8u, 8a)

Laras : Pelog Patet Barang

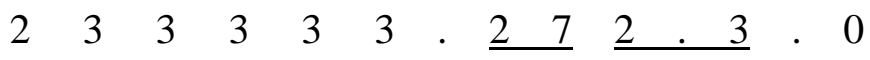

Lah ingmangke ka- di pun- di

$\begin{array}{lllllllll}6 & 7 & 2 & \underline{3.2} & 7 & \underline{6.7} & 2 & \underline{3.27} & 0\end{array}$

De-wa- ta no- ra sam- ba- da

$\begin{array}{lllllllllllll}2 & 3 & 3 & 3 & 5 & \underline{6.7} & 2 & \underline{3.27} & 0\end{array}$

Ngaru-napung sa- sam- ba- te

$\begin{array}{llllllllll}6 & 7 & 2 & \underline{3.2} & 7 & \underline{6.7} & 2 & \underline{3.2} 7 & 0\end{array}$

Anggu-gah wong la- gi nen- dra

$\begin{array}{lllllllllll}7 & 7 & 7 & \underline{7} & 2 & \underline{6.7} & 2 & \underline{3.2 .7} & & \end{array}$

Ki- nen u- mang- sah yu- da

$\begin{array}{lllllllllll}2 & 3 & 3 & 3 & 5 & \underline{6.7} & 2 & \underline{3.27} & 0\end{array}$

Nglabuhi wongnumbuk num-buk

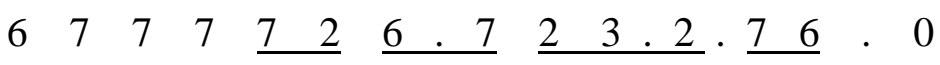

A- Kar-ya ru- sak- ing pra- ja 


\section{Jenis Lagu (Lagon)}

Kebiasaan pengucapan (salah kaprah) dan tidak adanya informasi tertulis secara historis, struktural dan kultural, akhirnya masyarakat sebagai pengguna sekaligus pelaku budaya tidak memahami hal yang sebenarnya, bahwa tembang dan lagu (lagon) sama pengucapan dan penggunaannya. Tembang sama dengan Sekar, syair, puisi. Lagu sama dengan Lagon, artinya nyanyian. Dinyanyikan berarti dilagukan, maksudnya disuarakan dengan menggunakan nada, titi laras pentatonic. Para pelaku kesenian Jawa dalam membawakan sebuah sajian biasanya berembuk terlebih dahulu. Misalnya, tembange apa..? lagu lagune piye...? jawabnya adalah; tembange Sinom, lagune Logondhang. Jelaslah kiranya, bahwa penyebutan tembang dan lagu sebenarnya adalah berbeda. Karena lagu (lagon) adalah nyanyian dengan nada dan titi laras tertentu, maka saya berpendapat bahwa kata "tembang" tidak tepat untuk penyebutan, misalnya; tembang anak-anak, tembang dolanan., dan semestinya untuk penyebutan nama tembang kinanthi, tembang pangkur, dan sebagainya. Sedangkan kata "lagu" lebih tepat untuk penyebutan, misalnya; lagu Ilir-ilir, lagu cublak-cublak suweng, dan sebagainya, dan tidak semestinya menyebut tembang cublak-cublak suweng, tembang ilir-ilir.

Bali yang masih melestarikan kebudayaan Jawa kuna (Jawa Bali) lagu (lagon) dengan titi laras tertentu dan tidak terikat guru lagu guru wilangan disebutnya dengan istilah gegendingan atau sekar rare, sedang di Jawa Timur dengan sebutan Kidung (Dinas P dan K Daerah Propinsi Daerah Tingkat I Jawa Timur, 1989) dan berbeda dengan pengertian kidung di Bali. Jenis tembang ini dinyanyikan oleh anak-anak sambil membuat permainan. Cara pengucapan oleh setiap anak-anak sering berubah. Akibatnya nyanyian jenis ini dalam perkembanganya mengalami perubahan-perubahan bentuk. Karena anak-anak tahunya menirukan apa yang didengar saja. Sifat nyanyian ini gembira, meriah, dengan diselingi permainan (Aryasa, 1984: 12).

Singkat kata, lagu atau lagon tidak termasuk dalam rumpun tembang, karena lagu adalah titi nada (laras), sehingga lebih tepat untuk penyebut lagu dalam syair atau puisi yang bersifat bebas tidak berstruktur tembang Gendhe, Tengahan maupun Macapat. Adapun ciri-ciri lagu (lagon) atau lelagon yaitu:

1. Tidak terikat guru lagu (pada lingsa)

2. Setiap gatra tidak terikat guru gatra (jumlah wanda) 
3. Bentuk lagunya bebas

4. Pada umumnya sifat lagunya gembira, meriah baik berisi permainan maupun sindiran.

\section{Tembang (Lagu) Dolanan Anak}

Menanamkan nilai luhur lewat tembang dan lagu bagi anak-anak, khususnya usia sekolah taman kanak-kanak dan sekolah dasar adalah sangat tepat dan seharusnya sejak lama dilaksanakan. Karena tembang dan lagu-lagu Jawa disetiap daerah, didalamnya terkandung ajarajaran budi luhur, sementara anak usia sekolah Tk dan SD ibarat kain putih yang masih kosong, sepatutnya dibekali dan ditempa dengan ajaran-ajaran budi luhur membentuk perilaku, sikap, karakter (watak).

Karakter dalam bahasa yang sederhana disamakan dengan watak, tabiat, perangai, atau sifat-sifat seseorang yang mencerminkan jati diri seseorang. Pengembangan karakter, dalam kehidupan manusia, menjadi sesuatu yang sangat penting dan strategis karena karakter sering kali diidentikan dengan budi pekerti atau akhlak.

Mengembangkan sifat kejujuran, kepercayaan, keterbukaan dan kearifan tentu saja diperlukan bagi semua manusia sehingga manusia dapat menjadi manusia yang lebih bermartabat. Pendidikan karakter yang baik dan bernar diharapkan akan menghasilkan manusiamanusia yang baik sehingga dapat menghasilkan kebudayaan yang tinggi dan bermartabat. Pendekatan pendidikan karakter yang tepat juga akan semporna bila dilakukan dengan pendekatan budaya, khususnya pendekatan budaya setempat.

Undang-undang Sisdiknas tahun 2003 menyatakan bahwa tujuan pendidikan nasional antara lain mengembangkan potensi didik untuk memiliki kecerdasan, kepribadian, dan akhlak mulia. Berikutnya, pada 2 Mei 2010 Menteri Pendidikan Nasional mendeklarasikan dimulainya pendidikan karakter bangsa. Pendidikan karakter bangsa penting dan menjadi fokus pendidikan nasional.

Saya tidak ingin berpanjang lebar tentang polemik sistim pendidikan nasional, tapi saya mengajak kepada seluruh komponen pelaku didik yang tidak lain adalah para guru, untuk bergandengan tangan, merapatkan barisan, mensatukan cipta rasa karsa dalam mencari-mencari dan terus mencari, sehingga menemukan cara yang tepat dan benar, penuh kesadran akan tugas mulianya sebagai pendidik. Karena saya berpandangan bahwa: 
Pendidikan karakter bukanlah mata pelajaran atau panduan bertindak, tetapi bersifat afektif, yaitu internalisasi nilai-nilai dalam pembelajaran diri yang tercermin dalam sikap dan perilaku.

Menanamkan nilai luhur lewat tembang anak-anak atau sekar lare (rare) pada saat sekarang, bukanlah sebuah usaha yang gampang, tidak akan segera dapat dirasakan hasilnya dalam waktu setahun dua tahun, sementara jam pembinaannya sangat terbatas, berbagi dengan mata pelajaran lainnya. Oleh karenanya, dibutuhkan kesadaran dan kerelaan dari para guru untuk menambah jam ekstra dalam pembinaan secara terus-menerus. Karena sasaran yang ingin dicapai tidak lain adalah pembentukan karakter anak sejak usia dini, yaitu halusnya budi pakerti, memantapkan rasa kebangsaan dan pencintai serta giat mempelajari kesusastraan jawa. Oleh sebab itu, dalam pembelajaran, hendaknya dengan materi-materi tembang yang sesuai dengan usia anak, yaitu dengan muatan sastra, isi tembang, lagu yang sekiranya dapat dipahami, akhirnya dapat dirasakan oleh anak. Pemahaman yang cukup atas hafalan lagunya, makna kalimat, serta isi dari tembangnya, akan menghidupkan (anggesangaken) jiwa anak (rohing lare) yang selaras dengan kehidupan berbangsa dan bernegara. Selanjutnya Ki Hadjar Dewantara mengatakan:

Kangge para guru ingkang baut ing sekar ngiras kenging kangge nyariosaken lelampahan, kawontenan tuwin dedongengan ing jaman kina, temahan ngindakaken seserepan lare tumrap kagunan lan kasusastran, kawruh gesang sasrawungan saha kabudayan Jawi (Ki Hajar, 1964: 8).

Akhirnya tidak berlebihan apabila saya berpendapat, bahwa pendidikan kesenian khususnya pelajaran tembang dan lagu untuk anak-anak TK dan SD menjadi amat penting peran dan fungsinya. Hal penting yang didapat dari olah tembang dan lagu adalah olah rasa (afektif), olah ketrampilan (psikomotorik), dan olah pikir (kognitif). Sebagai sarana pembentukan watak, sikap, dan perilaku. Musik, tembang, dan lagu bukan sekedar hiburan saja, tetapi sebagai alat perangsang kecerdasan emosi (Adelina, 2003). Selanjutnya, apabila penanaman budi luhur lewat tembang dan lagu sejak dini telah tertanam dengan baik dan benar, pada akhirnya akan melahirkan anak-anak yang muaranya akan ke jenjang pendidikan tinggi menjadi mahasiswa yang berkarakter. Hal tersebut seiring dengan nilai-nilai dasar pendidikan karakter yang diberlakukan dilingkungan pendidikan tinggi adalah; jujur, tangguh, cerdas, peduli, bermoral, kreatif, unggul dan mandiri.

Cara menyuarakan tembang dan lagu, pertama-tama yang harus diperhatikan yaitu posisi badan yang benar, badan lurus tegak baik dalam posisi duduk maupun berdiri, dada dilapangkan, 
perut dikempiskan, dan perlu diperhatikan konsentrasi harus terpusat terhadap tempo atau irama gamelan. Jangan lupa, amatilah terlebih dahulu tembang itu, berlaraskan pelog atau slendro, pathetnya apa, nem limo atau barang apabila pelog atau nem songo manyuro apabila slendro. Apabila sudah ketemu pathetnya. Suarakan lewat batin berdasarkan thintingan gamelan, agar mengetahui tinggi rendahnya nada itu dan disesuaikan dengan ambitus suara anak, sehingga mengetahui batas suara yang dimiliki terlalu rendah atau tinggi. Apabila suara sudah tepat dengan nada gamelan, selanjutnya menyuarakan tembang dan lagu bisa dimulai. Berikut contoh tembang anak-anak (sekar lare):

$$
\begin{aligned}
& \text { 1. Judul : NUMPAK SEPUR } \\
& \text { Laras : Slendro Patet Songo }
\end{aligned}
$$

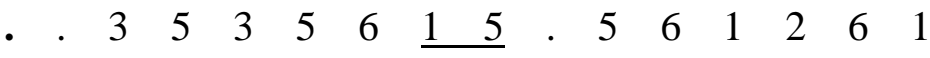

$$
\begin{aligned}
& \text { A-yonumpak se-pur mbayare se- ta- li }
\end{aligned}
$$

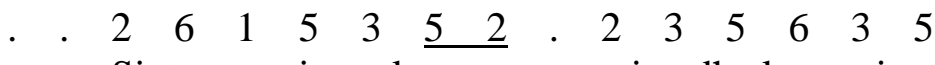

$$
\begin{aligned}
& \text { Sintenpengin mak-mur a- ja dha kurupsi }
\end{aligned}
$$

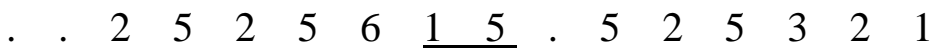

$$
\begin{aligned}
& \text { A-yo numpak se-pur mubengJawa Timur } \\
& \begin{array}{lllllllllllllll}
. & 6 & 6 & 6 & 6 & 6 & 6 & . & . & 2 & 3 & 5 & 6 & 3 & 5
\end{array} \\
& \text { Mbayar-e se-la-we mudun pa-sar so-re } \\
& \text { 2. Judul : CUBLAK SUWENG } \\
& \text { Laras : Slendro }
\end{aligned}
$$

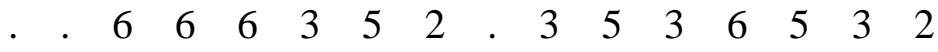

$$
\begin{aligned}
& \text { Cublak cublaksuweng suwenge ting gelen-der } \\
& \text { • } \begin{array}{lllllllllllllll}
3 & 5 & 3 & 6 & 5 & 3 & 2 & . & 2 & 6 & 1 & 2 & 3 & 2 & 2
\end{array} \\
& \text { Mambu ketundung Gudel tak empok le-ra le-re } \\
& \begin{array}{llllllllllllllll}
2 & 3 & 6 & 1 & 2 & 3 & 2 & 2 & 6 & . & 6 & 5 & 3 & 2 & 3 & 5
\end{array} \\
& \text { Sa-pangguyu de-lik-a- ke sir sir pongde-legosong } \\
& \begin{array}{llllllll}
6 & 6 & 5 & 3 & 2 & 3 & 5
\end{array} \\
& \text { Sir sirpongde-le gosong }
\end{aligned}
$$




\section{Tembang (Lagu) Dolanan Anak Sebagai Inspirasi Tarian Anak}

Tari adalah gerak, menari adalah melakungkan gerakan-gerakan yang telah tertata menurut alur yang teratur sesuai dengan maksud (gagasan integrative) yang ingin disampaikan. Dapatlah dikatakan bahwa tari ibarat bahasa dengan simbol-simbol gerak yang memiliki makna dalam setiap gerakannya tersebut.

Tari anak-anak yang berkembang dewasa ini lebih banyak menekankan pada segi gerak dan lagu tanpa memperhatikan pada kejiwaan dan estetis yang terkandung didalamnya. Seperti yang dikatakan oleh Maurice Barret bahwa pendidikan seni dapat membantu pembentukan pribadi, sebagai sarana penuang tradisi, dan dapat mengembangkan berpikir kreatif sekaligus menanamkan nilai sosial dan pengembangan individual (Maurice Barret, 1992: 106). Pada tingkatan Taman Kanak-kanak (TK) dan Sekolah Dasar (SD) diberikan pelajaran tentang tarian, tetapi seringkali seorang guru di tingkatan tersebut memberikan materi pembelajaran tarinya hanya dengan mendemonstrasikan gerak yang ditirukan oleh anak didiknya. Setelah itu guru mengoreksi gerak yang dilakukan oleh muridnya. Hal ini jelas tidak memberikan suatu muatan estetis dan pemahaman tentang tarian yang dibawakannya. Di sanggar-sanggar tari untuk tarian anak lebih ditekankan pada tarian klasik yang sulit untuk diikuti materinya sehingga para anakanak biasanya cepat bosan dalam mengikuti kegiatan tersebut. Keseluruhan yang terjadi di lapangan itu dikarenakan suatu jenis tarian diciptakan tidak sesuai dengan karakter dan porsinya bagi kalangan anak-anak.

Masa anak-anak merupakan dunia yang menyenangkan dengan segala realita dan fantasinya. Daya ingat anak-anak sangat tajam dan lebih cepat meniru dari segala bentuk yang dilihatnya. Dalam mengantisipasi kondisi tersebut diperlukan langkah-langkah konkrit untuk menggalakan penciptaan tarian yang diperuntukan bagi anak-anak. Bentuk tarian yang diciptakan oleh seorang seniman seharusnya disesuaikan dengan kemampuan anak dalam mencerna dan menirukan dari suatu gerakan itu. Pembentukan kepribadian anak yang disesuaikan dengan latar belakang budaya dan alamnya menjadikan anak akan lebih mencintai dan mengerti tentang lingkungan yang melingkupinya. Penciptaan tari anak-anak yang berlandaskan budaya lokal lingkungan dan alamnya memberikan pemahaman dan kesadaran bagi anak dalam memaknai dari kearifan lokal lingkungannya. Salah satunya yaitu dengan menginpirasi dari Tembang Dolanan anak. 
Lahirnya sebuah karya seni, seniman sepatutnya memiliki gambaran atau rancangan kerja berdasarkan konsep yang sudah ditentukannya, terlebih seniman akademik. Garap tari juga demikian, koreografer setelah melalui proses ngothong, gemblengake (membulatkan) ide atau gagasan, observasi. serta didukung pengalaman (apresiasi), selanjutnya menentukan rancangan bentuk garapan. Perancangan garapan seniman satu dengan seniman lainnya berbeda, tergantung dari pengalaman dan cara kerja menurut kebiasaan masing-masing. Setidaknya hal-hal yang berhubungan dengan rancangan garap meliputi, format komposisi (gerak dan pola lantai), durasi waktu, musik (alat musik dan jenis lagunya), dinamika (irama awal, tengah, dan akhir). Dalam garap tari anak meliputi: Gerak, Musik (gendhing/lagu), Drama, dan Artistik (rias, busana, dan properti).

Banyak seniman terlahir dengan segala persoalan hidup, pengalaman hidup, dan proses berkesenian. Pastinya, predikat kesenimanannya itu, atas pengakuan masyarakat, bukan dari siapapun (per-orangan atau lembaga), karena perjalanan panjangnya dalam berkesenian dan diterima oleh masyarakat. Dalam laku, baik langsung maupun tidak langsung, di sadari atau tidak, setiap seniman dengan caranya masing-masing pasti melakukan "Ngothong" (mengosongkan diri) "laku ngothong" artinya melakukan pengosongkan diri (sewiji, gembleng manunggal) mensatukan "tri purusa" yakni satunya pikiran, perasaan dan keinginan (nafsu). Pada bagian ini, seorang pangripta (pencipta) sadar sepenuhnya bahwa dia mendapatkan panggilan dari jiwanya dalam "darma" sebagai tugas hidup. Ini merupakan bagian dari proses pengalaman "religius" yang secara terus menerus dilakukan oleh seniman, yang dituangkan dalam teks Tembang Dolanan anak. Ketertarikan akan objek-objek memunculkan ide (gagasan) sebagai contoh, yaitu pada Tembang Dolanan Anak yang berjudul Numpak Sepur dan Cublak Suweng

\section{Penutup}

Sudah cukup lama tembang atau lagu dolanan anak-anak (tradisi) kurang mendapat perhatian dilingkungan pendidikan sekolah, kalah dengan lagu-lagu kekinian berbau modern. Seiring dengan hal tersebut, kemerosotan nilai-nilai luhur, ahklak, sikap, etika semakin tidak dapat dikontrol bahkan cenderung meresahkan baik keluarga maupun masyarakat. Maka untuk menanamkan nilai-nilai moral dan etika sebagai dasar pendidikan karakter yang berbudi luhur 
bagi anak didik, hendaknya kembali menggunakan tembang dan lagu-lagu dolanan tradisi kekuatan lokal, atau lagu-lagu ciptaan baru yang kandungan isinya sama.

Pengembangan karakter, dalam kehidupan manusia, menjadi sesuatu yang sangat penting dan strategis karena karakter sering kali diidentikan dengan budi pekerti atau akhlak. Mengembangkan sifat kejujuran, kepercayaan, keterbukaan dan kearifan tentu saja diperlukan bagi semua manusia sehingga manusia dapat menjadi manusia yang lebih bermartabat. Pendidikan karakter yang baik dan benar diharapkan akan menghasilkan manusia-manusia yang baik sehingga dapat menghasilkan kebudayaan yang tinggi dan bermartabat.

Memahami arti dan makna yang terkandung dalam tembang dan lagu dolanan anak-anak yang bernafaskan tradisi atau kreasi yang bernafas tradisi, maka selanjutnya, kepada para guru atau pamong pengampu hendaknya juga memberikan tehnik bersuara (nembang) dengan cara yang benar. Posisi badan (duduk/ berdiri), posisi dada dan perut, serta konsentrasi yang terpusat pada irama yang tepat. Mengamati isi yang terkandung dalam tembang (syair), memperhatikan laras (nada) pelog atau slendro, dengan menyesuaikan ambitus suara anak. Selanjutnya hal yang tidak kalah penting adalah merumuskan dan menyusun evaluasi untuk keberhasilan ranah afektifnya, sehingga salah satu tujuan pembelajaran yang dalam hal ini pembentukan perilaku, sikap, dan karakter anak didik dapat diketahui tingkat keberhasilannya.

Tembang Dolanan Anak dapat menjadi sebuah inspirasi dalam pembuatan tarian anak. Hal itu secara berkesinambungan dikaitkan dengan karakter yang dimunculkan dalam syair-syair yang mengalir dalam alunan melodinya. Pendidikan karakter yang disesuaikan dengan sifat dan tingkah laku anak memunculkan sebuah pola tingkah laku yang harmonis antara gerakan dan karakter anak. Tembang Dolanan Anak yang berkembang di masyarakat dapat dijadikan sebuah acuan dalam menciptakan sebuah tarian anak. 


\section{Daftar Pustaka}

Adelina. (2003). Musik Mencerdaskan Anak dan Menyembuhkan Penyakit. Diambil 2005, http://www.w3.org-/TR/html4/loose.dtd.

Budiyasa, Nyoman. Drs \& Ketut Purnawan, Drs. (1997). Submata Pelajaran Tembang. Klaten: Intan Pariwara.

Cambel, D. (2001). Efek Mozart Bagi Anak-Anak. (Terj. Alex Trikantjono W). Jakarta: PT. Gramedia Pustaka Utama.

Dewantara, Ki Hadjar. (1964). Serat Sari Swara Djilid I. Djakarta: P.N. Pradnjaparamita.

Murdiati \&Untung Muljono. (1983). Dasar-Dasar Belajar Tembang Gaya Yogyakarta. Yogyakarta: Akademi Seni Tari Indonesia

Padmo Soekotjo, S. (1960). Ngengrengan Kasusastran Djawa II. Yogyakarta: Hien Hoo Sing.

Prawiroatmojo, S. (1957). Bausastra Jawa Indonesia. Surabaya.

WM. Aryasa, I \& dkk. (1984). Pengetahuan Karawitan Bali. Denpasar: Departemen Pendidikan Dan kebudayaan Direktorat Jendral Kebudayaan Proyek Pengembangan Kesenian Bali.

Yogo Wicaksono, Herwin. 2007. Peranan Etnomusikologi Dalam Pendidikan

Dasar, Seminar Nasional Pendidikan Seni Musik, Jurusan Seni Musik Fakultas Bahasa dan Seni Universitas Negeri Yogyakarta.

Departemen Pendidikan Dan kebudayaan Direktorat Jendral Kebudayaan Proyek Pengembangan Kesenian Bali.

. (1980). Himpunan Tembang mataram. Yogyakarta: Bidang kesenian Kanwil Dep. P dan K Prop. DIY.

. (1996). Kidung Jawa Timur. Surabaya: Dinas P dan K Daerah Propinsi

Daerah Tingkat I Jawa Timur. 